\title{
PENGARUH PROFITABILITAS, LEVERAGE, GROWTH, DAN FREE CASH FLOW TERHADAP DIVIDEND PAYOUT RATIO PERUSAHAAN DENGAN MEMPERTIMBANGKAN CORPORATE GOVERNANCE SEBAGAI VARIABEL INTERVENING
}

\author{
Muhammad Akhyar Adnan \\ Univeristas Muhammadiyah Yogyakarta \\ e-mail: ibnu8adnan@yahoo.com \\ Barbara Gunawan \\ Universitas Muhammadiyah Yogyakarta \\ e-mail: barbaragunawan@yahoo.co.id \\ Ratri Candrasari \\ Univeristas Muhammadiyah Yogyakarta \\ e-mail: era@umy.ac.id
}

\begin{abstract}
This study is aimed at analyzing the influence of Profitability, Leverage, Growth, and, Free Cash Flow to the Company's Dividend Payout Ratio, by considering the Corporate Governance as an intervening variable. Subjects in this study were the companies ranked in the Corporate Governance Perception Index ranking (CGPI) conducted by the Indonesian Institute for Corporate Governance (IICG) in 20062011 which published their financial statements as of December 31. The samples were 81 companies selected using purposive sampling method. The analysis tools are simple regression and path analysis.The research found that only three hypotheses are accepted, while others are rejected. The research concludes that profitability has no positive influence on dividend payout ratio; leverage negatively affect the dividend payout ratio; growth negatively affect the dividend payout ratio; free cash flow positively effect on dividend payout ratio, no positive effect of profitability on the Corporate Governance, leverage positively influencesthe corporate governance; growth has no positive influence on corporate governance; free cash flow does not influence the Corporate Governance, Corporate Governance does not affect the dividend payout ratio, and the Corporate Governance is accepted to be added in the model as an intervening variable.
\end{abstract}

Keywords: dividend payout ratio (DPR), profitability (ROA), leverage (DER), growth (GROWTH), free cash flow $(F C F)$, Corporate Governance (CG)

\begin{abstract}
Abstrak
Penelitian ini bertujuan untuk menganalisis profitability, leverage, growth, dan free cash flow terhadap dividen payout ratio perusahaan dengan mempertimbangkan corporate governance sebagai variabel intervening. Subjek penelitian ini adalah perusahaan yang dirangking oleh Indonesian Institute for Corporate Governance (IICG) tahun 2006-2011 yang mempublikasikan laporan keuangan di 31 Desember. Sampel penelitian ini adalah 81 perusahaan yang dipilih dengan purposive sampling method. Alat analisis adalah simple regression dan path analysis. Penelitian ini menemukan hanya tiga hipotesis yang diterima, hipotesis lainnya ditolak. Penelitian ini menyimpulkan bahwa profitability tidak berpengaruh terhadap dividend payout ratio, leverage berpengaruh negatif terhadap dividen payout ratio, growth berpengaruh negatif terhadap dividend payment ratio, free cash flow berpengaruh positif terhadap dividend payout ratio, tidak ada pengaruh positif probitability terhadap corporate governance, leverage positif mempengaruhi corporate governance, growth tidak berpengaruh positif terhadap corporate governance, free cash flow tidak berpengaruh terhadap corporate governance, corporate governance tidak
\end{abstract}


berpengaruh terhadap dividend payout ratio, dan corporate governance diterima untuk ditambahkan dalam model sebagai variabel intervening.

Kata kunci: dividend payout ratio (DPR), profitability (ROA), leverage (DER), growth (GROWTH), free cash flow (FCF), Corporate Governance (CG)

\section{PENDAHULUAN}

Dalam suatu perusahaan, salah satu tujuan yang ingin dicapai suatu adalah meningkatkan kesejahteraan dan kekayaan pemegang saham melalui peningkatkan nilai perusahaan. Peningkatan nilai perusahaan dapat dicapai jika perusahaan mampu beroperasi dan mencapai keuntungan yang ditargetkan (Sulistiyowati 2010). Melalui keuntungan yang diperoleh, perusahaan mampu membagikan dividen kepada pemegang saham, meningkatkan pertumbuhan perusahaan, dan mempertahankan kelangsungan hidup perusahaan.

Keputusan pembayaran dividen (divi dend payout ratio) merupakan suatu masalah yang sering dihadapi perusahaan. Manajemen sering mengalami kesulitan untuk memutuskan apakah akan membagi dividennya atau akan menahan laba untuk diinvestasikan kembali pada proyek-proyek yang menguntungkan guna untuk meningkatkan pertumbuhan perusahaan. Pertimbangan yang diperlukan dalam membuat keputusan dividen adalah kelangsungan hidup dan pertumbuhan perusahaan (Hatta 2002). Berkaitan dengan dividend payout ratio tersebut, terlihat adanya konflik kepentingan antara pemegang saham dan manajemen perusahaan itu sendiri.

Faktor yang berpengaruh sangat penting dalam keputusan dividend payout ratio suatu perusahaan adalah profitabilitas. Profitabilitas merupakan kemampuan perusahaan untuk menghasilkan laba. Semakin tinggi profitabilitas, maka dividen yang dibayarkan semakin tinggi. Penelitian yang dilakukan oleh Suharli (2007), Sugiarto (2008), dan Marpaung dan Hadianto (2009) menunjukkan bahwa profitabilitas berpengaruh positif dan signifikan terhadap dividend payout ratio. Namun, penelitian yang dilakukan oleh Prihantoro (2003) mengemukakan bahwa profitabilitas tidak mempunyai pengaruh yang signifikan terhadap dividend payout ratio.
Faktor lain yang juga penting dalam keputusan dividend payout ratio adalah leve rage. Rozeff (1982) menyatakan semakin besar leverage perusahan maka dividen yang dibayarkan lebih rendah. Hal ini bertujuan untuk mengurangi ketergantungan pada pendanaan yang berasal dari eksternal perusahaan sehingga semakin besar proporsi hutang yang digunakan untuk struktur modal suatu perusahaan, maka akan semakin besar pula jumlah kewajibannya yang akan memengaruhi besar kecilnya dividen yang akan dibagikan. Faktor lain yang juga berpengaruh terhadap dividend payout ratio adalah growth atau pertumbuhan perusahaan. Semakin cepat tingkat pertumbuhan suatu perusahaan, makin besar juga kebutuhan dana untuk waktu mendatang untuk membiayai pertumbuhanya (Riyanto 2001). Perusahaan tersebut biasanya akan lebih senang untuk menahan pendapatannya daripada dibayarkan sebagai dividen dengan mengingat batasan-batasan biayanya. Apabila perusahaan telah mencapai tingkat pertumbuhan sedemikian rupa sehingga perusahaan telah mencapai tingkat pertumbuhan yang mapan, dimana kebutuhan dananya dapat dipenuhi dengan dana yang berasal dari pasar modal atau sumber dana ekstern lainya, maka keadaanya adalah berbeda. Dalam hal yang demikian perusahaan dapat menetapkan divi dend payout ratio yang tinggi.

Menurut Rosdini (2009) aliran kas bebas (free cash flow) merupakan kas perusahaan yang dapat didistribusikan kepada kreditor atau pemegang saham yang tidak digunakan untuk modal kerja (working capital) atau investasi pada aset tetap. Aliran kas bebas menunjukkan gambaran bagi investor bahwa dividen yang dibagikan oleh perusahaan tidak sekedar strategi menyiasati pasar dengan maksud meningkatkan nilai perusahaan. Ada kesan kuat bahwa hubungan berbagai variabel di atas belum bersifat konklusif, selain belum konsisten, bila dibandingkan beberapa hasil penelitian 
terdahulu. Oleh karena itu adalah menarik untuk mengkaji lagi: Apakah profitabilitas, leverage, growth, dan free cash flow berpengaruh terhadap dividend payout ratio dengan corporate governance sebagai variabel intervening baik variabel independen yang dimasukkan memiliki pengaruh secara bersamasama terhadap variabel dependen atau variabel independen yang dimasukkan memiliki pengaruh terhadap variabel dependen secara individu. Tujuan penelitian ini adalah untuk menguji apakah profitabilitas, leverage, growth, dan free cash flow berpengaruh terhadap dividend payout ratio dengan corporate governance sebagai variabel intervening baik variabel independen yang dimasukkan memiliki pengaruh secara bersama-sama terhadap variabel dependen atau variabel independen yang dimasukkan memiliki pengaruh terhadap variabel dependen secara individu.

\section{TINJAUAN PUSTAKA DAN PERUMUSAN HIPOTESIS}

\section{Profitabilitas dan dividend payout ratio}

Menurut Suharli (2007) pihak manajemen akan membayarkan dividen untuk memberikan sinyal mengenai keberhasilan perusahaan dalam membukukan profit. Semakin besar keuntungan yang diperoleh maka akan semakin besar pula kemampuan perusahaan untuk membayar dividen. Dengan demikian profitabilitas mutlak diperlukan untuk perusahaan apabila akan membayar dividen. Hal ini sesuai dengan teori signaling dan teori residual devidend policy. Teori signaling menyatakan bahwa pembayaran dividen merupakan sinyal bagi investor luar mengenai prospek perusahaan dimasa datang, sehingga perusahaan yang membagikan dividen akan menunjukkan bahwa perusahaan tersebut memiliki ekpektasi yang baik dimasa yang akan datang. Teori residual dividend policy menyatakan bahwa perusahaan membayarkan dividen hanya jika terdapat kelebihan dana atas laba perusahaan yang digunakan untuk membiayai proyek yang telah direncanakan.

Penelitian yang dilakukan oleh Suharli (2007), Sugiarto (2008), dan Marpaung and
Hadianto (2009) terbukti bahwa profitabilitas berpengaruh positif dan signifikan terhadap dividend payout ratio namun, penelitian yang dilakukan oleh Sulistiyowati (2010) mengemukakan bahwa profitabilitas tidak mempunyai pengaruh yang signifikan terhadap dividend payout ratio. Berdasarkan teori dan hasil penelitian terdahulu maka hipotesis yang diajukan adalah:

H1: Proftabilitas berpengaruh positif terhadap dividend payout ratio.

\section{Leverage dan dividend payout ratio}

Peningkatan hutang akan memengaruhi besar kecilnya laba bersih yang tersedia bagi para pemegang saham termasuk dividen yang akan diterima. Prihantoro (2003) mengungkapkan Debt to Equity Ratio (DER) mencerminkan kemampuan perusahaan memenuhi seluruh kewajibannya, yang ditunjukkan oleh berapa bagian modal sendiri yang digunakan untuk membayar hutang. Menurut Suharli dan Sofyan (2004) semakin besar leverage perusahan maka cenderung untuk membayar dividennya lebih rendah dengan tujuan untuk mengurangi ketergantungan pada pendanaan secara eksternal sehingga semakin besar proporsi hutang yang digunakan untuk struktur modal suatu perusahaan, maka akan semakin besar pula jumlah kewajibannya yang akan memengaruhi besar kecilnya dividen yang akan dibagikan. Hal ini sesuai dengan penelitian Prihantoro (2003) yang menemukan leveage berpengaruh signifikan terhadap dividend payout ratio.

Penelitian yang dilakukan Sulistiyowati (2010) menemukan bahwa leverage tidak memberikan pengaruh yang signifikan terhadap kebijakan mengenai jumlah pembagian dividen. Berdasarkan teori dan hasil penelitian terdahulu maka hipotesis yang diajukan adalah:

$\mathrm{H} 2$ : Leverage berpengaruh negatif terhadap dividend payout ratio.

\section{Growth dan dividend payout ratio}

Tingkat pertumbuhan perusahaan merupakan salah satu faktor yang memengaruhi dividend payout ratio (Tampubolon 2005). Semakin 
cepat tingkat pertumbuhan suatu perusahaan, maka semakin besar kebutuhan dana yang diperlukan untuk membiayai pertumbuhan tersebut. Semakin besar kebutuhan dana untuk waktu mendatang maka perusahaan lebih senang untuk menahan labanya daripada membayarkannya sebagai dividen kepada pemegang saham. Teori contract menyatakan bahwa hubungan antara kebijakan investasi dan dividen dapat diidentifikasi melalui arus kas perusahaan, yaitu semakin besar jumlah investasi dalam satu periode tertentu, akan semakin kecil dividen yang diberikan. Perusahaan yang sedang mengalami masa pertumbuhan akan banyak membutuhkan banyak dana untuk membiayai proyek investasi dibandingkan membagikan dividen kepada pemegang saham.

Penelitian yang dilakukan oleh Suharli and Sofyan (2004) dan Marpaung and Hadianto (2009) menemukan bahwa growth berpengaruh signifikan terhadap dividend payout ratio namun, penelitian yang dilakukan Sulistiyowati (2010) tidak menemukan adanya pengaruh antara pertumbuhan dengan dividend payout ratio. Berdasarkan teori dan hasil penelitian terdahulu maka hipotesis yang diajukan adalah:

H3: Growth berpengaruh negatif terhadap dividend payout ratio.

\section{Free cash flow dan dividend payout ratio}

Rosdini (2009) mendefinisikan free cash flow sebagai aliran kas diskresioner yang tersedia bagi perusahaan. Free cash flow dapat digunakan untuk penggunaan diskresioner seperti akuisisi dan pembelanjaan modal dengan orientasi pertumbuhan (growth-oriented), pembayaran hutang, dan pembayaran kepada pemegang saham baik dalam bentuk dividen. Semakin besar freecash flow yang tersedia dalam suatu perusahaan, maka semakin sehat perusahaan tersebut karena memiliki kas yang tersedia untuk pertumbuhan, pembayaran hutang, dan dividen. Jadi, semakin tinggi free cash flow perusahaan semakin tinggi pula dividen yang dibayarkan perusahaan, karena perusahaan memiliki cukup kas yang tersedia. Penelitian yang dilakukan oleh Rosdini (2009) menemukan bahwa free cash flow berpengaruh positif terhadap dividend payout ratio. Berdasarkan teori dan hasil penelitian terdahulu maka hipotesis yang diajukan adalah: H4: Free cash flow berpengaruh positif terhadap dividend payout ratio.

\section{Profitabilitas danCorporate Governance}

Corporate governance mengarahkan pengelolaan perusahaan pada upaya pencapaian profit dan sustainability secara seimbang (Daniri 2006). Pencapaian keuntungan tersebut merupakan wujud pemenuhan pemegang saham (shareholder) dan tidak dapat dilepaskan dari upaya pencapaian sustainability yang merupakan wujud pemenuhan kepentingan para stakeholders.

Perusahaan yang memperoleh pendapatan yang lambat atau profitabilitas yang sedikit maka cenderung akan mengumumkan lebih banyak tentang pelaksanaan CG guna melepaskan tekanan dari pasar (Kusumawati 2007). Penelitian yang dilakukan oleh dan Darmawati (2006) dan Kusumawati (2007) menemukan bahwa profitabilitas berpengaruh negatif signifikan terhadap dividend payout ratio. Berdasarkan teori dan hasil penelitian terdahulu maka hipotesis yang diajukan adalah:

$\mathrm{H}_{5}$ : Profitabilitas berpengaruhnegatif terhadap Corporate governance.

\section{Leverage dan Corporate governance}

Menurut Faisal (2006) leverage dapat mempresentasikan sebuah pengendalian eksternal dari corporate governance. Pemegang utang (debtholders) berkepentingan untuk melindungi investasinya dalam perusahaan dan akan secara aktif memonitor seberapa besar tingkat leverage perusahaan tersebut.

Black, Jang, dan Kim (2006) menyatakan bahwa perusahaan yang memiliki tingkat utang yang tinggi dalam struktur modalnya akan cenderung menjadi subjek untuk dikenai pengawasan oleh kreditor yang lebih ketat yang dinyatakan dalam kontrak utang yang dibuat, kreditor sangat berkepentingan dengan praktik governance dari debiturnya dan me- 
miliki kekuasaan yang lebih besar dibandingkan pemegang saham untuk memaksa perusahaan meningkatkan kualitas corporate governance perusahaan.

Darmawati (2006) dan Sulistiyowati (2010) yang menyatakan bahwa leverage berpengaruh signifikan terhadap kualitas penerapan corporate governance. Berdasarkan teori dan hasil penelitian terdahulu maka hipotesis yang diajukan adalah:

$\mathrm{H}_{6}$ : Leverage berpengaruh positif terhadap Corporate governance.

\section{Growth dan Corporate Governance}

Menurut Daniri (2006) manfaat yang diberikan dari penerapan CG untuk mengurangi biaya modal sebagai dampak dari pengelolaan perusahan yang baik yang menyebabkan tingkat bunga atas dana oleh perusahaan semakin kecil seiring dengan turunnya tingkat resiko perusahaan dapat dijadikan pilar utama pendukung tumbuh kembangnya perusahaan dalam waktu jangka panjang. Pada umumnya perusahaan yang memiliki pertumbuhan tinggi membutuhkan dana tambahan untuk melakukan ekspansi sehingga mendorong perusahaan untuk melakukan perbaikan dalam penerapan CG dalam rangka menurunkan biaya modal (Black, Jang, dan Kim 2006) menyatakan bahwa growth berpengaruh terhadap CG. Berdasarkan teori dan hasil penelitian terdahulu maka hipotesis yang diajukan adalah:

$\mathrm{H}_{7}$ : Growth berpengaruh positif terhadap Corporate governance.

\section{Free cash flow dan Corporate governance}

Dividend payout ratio merupakan penggunaan laba bersih setelah pajak yang akan dibagikan kepada para pemegang saham dan berapa besar bagian laba bersih yang akan digunakan untuk membiaya investasi perusahaan. Apabila perusahaan memilih untuk membagikan laba yang diperolehnya dalam bentuk dividen, maka akan mengurangi retained earnings dan selanjutnya mengurangi total sumber dana internal. Sebaliknya, jika perusahaan memilih untuk menahan laba yang diperolehnya, maka kemampuan pembentukan dana internal akan semakin besar. Jadi, semakin tinggi free cash flow perusahaan maka akan semakin tinggi pula CG yang diterapkan suatu perusahaan. Aliran kas yang baik membuktikan bahwa dalam suatu perusahaan tersedia kas yang cukup sehingga diperlukan tata kelola perusahaan yang lebih baik juga agar dana yang ada bisa digunakan sesuai dengan porsinya. Berdasarkan teori dan hasil penelitian terdahulu maka hipotesis yang diajukan adalah:

$\mathrm{H}_{8}$ : Free cash flow berpengaruh positif terhadap Corporate governance.

\section{Corporate Governance dan Dividend Payout ratio}

Menurut Sulistiyowati (2010) tatakelola perusahaan yang baik yang merupakan bentuk dari perlindungan investor terhadap rasio pembayaran dividen. Teori keagenan menjelaskan bahwa dengan adanya corporate governance berfungsi sebagai alat untuk memberikan keyakinan kepada investor bahwa pemegang saham akan menerima return atas dana yang telah diinvestasikan.

Perusahaan yang melaksanakan corporate governance dapat mendatangkan pertambahan yang signifikan untuk devidend to cash flow ratio (Kowalewski, Stetsyuk, dan Talavera 2007). Hal ini juga sejalan dengan Jiraporn, Kim, dan Kim (2011) dan Sulistiyowati (2010) yang menyatakan bahwa perusahaan dengan kualitas yang baik akan membayarkan dividen yang lebih besar. Berdasakan teori dan hasil penelitian terdahulu maka hipotesis yang diajukan adalah:

$\mathrm{H}_{9}$ : Corporate Governance berpengaruh negatif terhadap dividend payout ratio.

$\mathrm{H}_{10}$ : Profitabilitas, leverage, growth, dan free cash flow berpengaruhterhadap dividend payout ratio dengan Corporate Governance sebagai variabel intervening.

\section{METODA PENELITIAN}

\section{Model Penelitian}

Berdasarkan uraian telaah literatur di atas, dapat dibangun model penelitian dalam gambar berikut ini: 


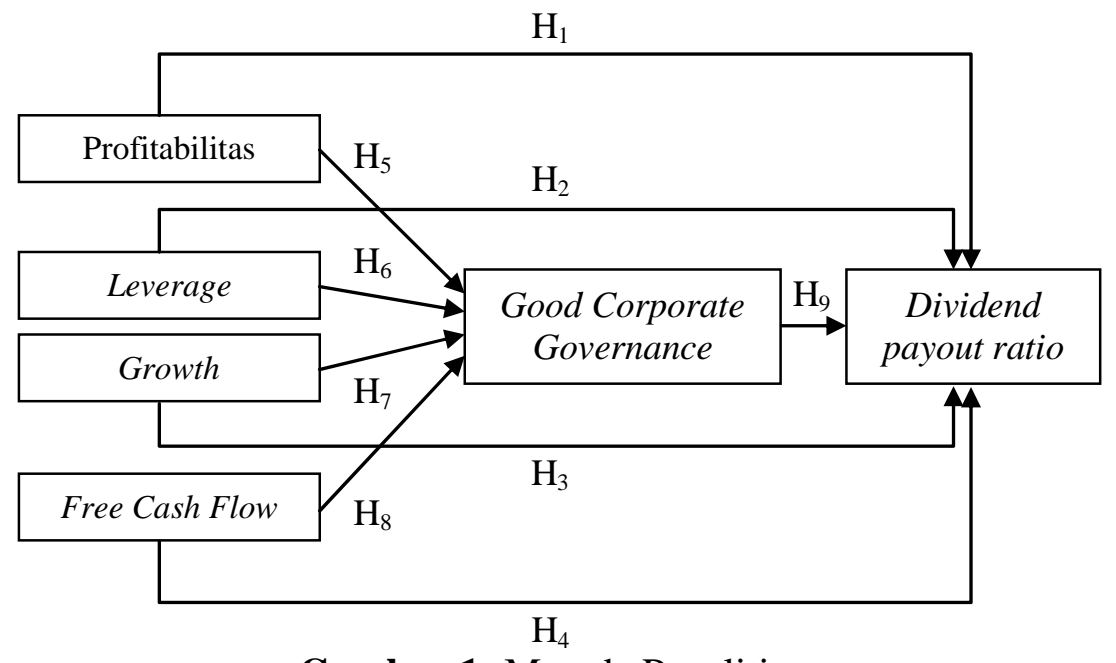

Gambar 1: Metode Penelitian

Tabel 1: Definisi Operasional Variabel

\begin{tabular}{|c|c|c|}
\hline Variabel Dependen & Definisi & Pengukuran \\
\hline $\begin{array}{l}\text { Dividend payout ratio } \\
\text { (DPR) }\end{array}$ & $\begin{array}{l}\text { Penggunaan laba yang menjadi hak para pemegang saham yaitu } \\
\text { pembagian laba dalam jumlah dividen yang dibayarkan } \\
\text { tergantung dari kebijakan setiap perusahaan (Sulistiyowati, } \\
\text { 2010). }\end{array}$ & $D P R=\frac{\text { Dividen }}{\text { Laba Bersih }}$ \\
\hline Variabel Independen & Definisi & Pengukuran \\
\hline Profitabilitas (ROA) & Kemampuan manajemen untuk memperoleh laba. & ROA $=\frac{\text { LabaBersih }}{\text { Total Aktiva }}$ \\
\hline Leverage(DER) & $\begin{array}{l}\text { Kemampuan perusahaan untuk menggunakan aktiva atau } \\
\text { dana yang mempunyai beban tetap untuk memperbesar } \\
\text { tingkat penghasilan bagi pemilik perusahaan. }\end{array}$ & $D E R=\frac{\text { Total Kewajiban }}{\text { Total Ekuitas }}$ \\
\hline Growth & $\begin{array}{l}\text { Perusahaan yang berkembang adalah perusahaan yang } \\
\text { mengalami peningkatan pertumbuhan dalam perkembangan } \\
\text { usahanya dari tahun ke tahun. }\end{array}$ & $\begin{array}{l}\text { Total Asset Growth } \\
\qquad=\frac{\left(\text { asset }_{t}-\text { asset }_{t-1}\right)}{\text { asset }_{t-1}}\end{array}$ \\
\hline Free cash flow (FCF) & $\begin{array}{l}\text { Free Cash Flow bagi perusahaan merupakan gambaran dari } \\
\text { arus kas yang tersedia untuk perusahaan dalam suatu periode } \\
\text { akuntansi, setelah dikurangi dengan biaya operasional dan } \\
\text { pengeluaran lainnya (Hatta, 2002). }\end{array}$ & $\begin{array}{l}\mathrm{FCF}=\text { Arus kas dari } \\
\text { kegiatan operasional }- \\
\text { Pengeluaran modal. }\end{array}$ \\
\hline Variabel Intervening & Definisi & Pengukuran \\
\hline $\begin{array}{l}\text { Corporate } \\
\text { Governance }(\mathrm{CG})\end{array}$ & $\begin{array}{l}\text { Hubungan partisipan dalam menentukan arah dan kinerja } \\
\text { (Monks dan Minow, } 1961 \text { dalam Darmawati, 2005) }\end{array}$ & $\begin{array}{l}\text { Golongan-Golongan: } \\
\mathbf{A = 8 5 , 0 0 - 1 0 0 , 0 0 / S a n g a t ~} \\
\text { Terpercaya,B=70,00- } \\
\mathbf{8 4 , 9 9 / T e r p e r c a y a , C = 5 5 , 0 0 -} \\
\text { 69,99/Cukup Terpercaya }\end{array}$ \\
\hline
\end{tabular}

\section{Subyek Penelitian dan Jenis Data}

Sampel yang digunakan dalam penelitian ini adalah perusahaan yang masuk dalam pemeringkatan Corporate Governance Perception Index (CGPI) yang dilakukan oleh The Indonesian Institute for Corporate Governance (IICG) tahun 2006-2011 serta menerbitkan laporan keuangan per 31 Desember.

Jenis data yang digunakan adalah data sekunder yang bersumber dari laporan keuangan perusahaan yang dipublikasikan di Bursa Efek Indonesia dan situs resmi perusahaan sampel.

\section{Teknik Pengambilan Sampel}

Penentuan sampel dalam penelitian ini dilakukan dengan menggunakan metode purposive sampling, dengan kriteria sebagai berikut:

1. Perusahaan yang masuk dalam pemeringkatan penerapan corporate governance 
yang dilakukan oleh IICG pada tahun 20062011 berupa skor pemeringkatan CGPI.

2. Perusahaan yang membagikan keuntungan berupa dividen kepada para pemegang saham pada tahun pemeringkatan CGPI.

3. Perusahaan yang terdaftar di BEI dan mepublikasikan laporan keuangan au ditan per 31 Desember serta dinyatakan dalam satuan mata uang rupiah.

\section{Teknik Pengumpulan Data}

Teknik pengumpulan data dalam penelitian ini dilakukan dengan teknik dokumentasi, yaitu teknik yang mendokumentasikan data yang telah dipublikasikan. Data dokumentasi diperoleh dari database pojok BEI Universitas Muhammadiyah Yogyakarta dan situs resmi perusahaan sampel.

\section{Definisi Operasional Variabel}

(lihat tabel 1)

\section{Uji Kualitas Data}

Sebelum dilakukan uji hipotesis, terlebih dahulu dilakukan uji kualitas data yaitu uji asumsi klasik. Uji asumsi klasik terdiri dari:

1. Uji Multikolinearitas, bertujuan untuk menguji apakah ditemukan adanya korelasi antar variabel independen.

2. Uji Autokorelasi, bertujuan untuk menguji apakah dalam suatu model regresi terdapat korelasi antara kesalahan pada periode $\mathrm{t}$ dengan periode $\mathrm{t}-1$.

3. Uji Heteroskedastisitas, yaitu suatu pengujian untuk melihat apakah data mempunyai varian yang sama (homogen) atau data mempunyai varian yang tidak sama (heterogen).

4. Uji Normalitas, untuk menguji apakah data berdistribusi normal atau tidak. Model regresi yang baik adalah model regresi yang berdistribusi normal.

\section{Uji Hipotesis dan Analisis Data}

1. Teknik analisis data yang digunakan dalam penelitian ini adalah:

a. Uji Statistik Deskriptif

Analisis ini disajikan dengan menggunakan tabel statistic descriptive yang memaparkan nilai minimum, nilai maksimum, nilai ratarata (mean), dan standar deviasi (standard deviation).

b. Regresi berganda

Dalam regresi berganda digunakan untuk mengetahui apakah hipotesis penelitian terbukti signifikan atau tidak signifikan, dengan persamaan sebagai berikut:

$$
\begin{aligned}
& \mathrm{DPR}_{\mathrm{it}}=\beta \mathrm{o}+\beta_{1} \mathrm{ROA}_{\mathrm{it}}+\beta_{2} \mathrm{DER}_{\mathrm{it}}+\beta_{3} \mathrm{GROWTH}_{\mathrm{i}} \\
& { }_{\mathrm{t}}++\beta_{4} \mathrm{FCF}_{\mathrm{it}}+\mathrm{e} \\
& \mathrm{CG}_{\mathrm{it}}=\beta \mathrm{o}+\beta_{1} \mathrm{ROA}_{\mathrm{it}}+\beta_{2} \mathrm{DER}_{\mathrm{it}}+\beta_{3} \mathrm{GROWTH}_{\mathrm{it}} \\
& +\beta_{6} \mathrm{FCF}_{\mathrm{it}}+\mathrm{e}
\end{aligned}
$$

\section{c. Path Analysis (Diagram Jalur)}

Path analysis digunakan untuk menggambarkan pola hubungan yang mengungkapkan pengaruh seperangkat variabel terhadap variabel lainnya, baik secara langsung maupun tidak langsung melalui variabel lain sebagai variabel intervening. Suatu variabel dikatakan sebagai variabel intervening jika hubungan tidak langsung lebih besar dari hubungan langsung.

2. Pengujian hipotesis

a. Uji Koefisien Determinasi $\left(\mathrm{R}^{2}\right)$

Koefisien determinasi digunakan untuk mengetahui prosentase sumbangan pengaruh serentak variabel-variabel bebas terhadap variabel terikat.

b. Uji Nilai t

Uji t digunakan untuk menguji secara parsial masing-masing variabel.

c. Uji Nilai $F$

Uji F digunakan untuk menunjukkan apakah semua variabel bebas dalam model penelitian mempunyai pengaruh secara bersama-sama terhadap variabel terikat.

d. Path Analysis (diagram jalur)

Path analysis digunakan untuk menggambarkan pola hubungan yang mengungkapkan pengaruh seperangkat variabel terhadap variabel lainnya, baik secara langsung maupun tidak langsung melalui variabel lain sebagai variabel intervening. Dalam diagram jalur untuk menerima atau menolak hipotesis digunakan nilai koefisien pengaruh langsung dan tidak langsung. Hipotesis diterima atau variabel dikatakan sebagai variabel inter- 
vening jika nilai koefisien hubungan tidak langsung lebih besar dari nilai koefisien hubungan langsung.

\section{HASIL DAN PEMBAHASAN}

\section{Deskripsi Obyek Penelitian}

Obyek penelitian yang digunakan dalam penelitian ini adalah perusahaan yang masuk dalam pemeringkatan Corporate Governance Perception Index (CGPI) yang dilakukan oleh The Indonesian Institute for Corporate Governance (IICG) tahun 2006-2011 serta menerbitkan laporan keuangan perusahaan yang dipublikasikan di Bursa Efek Indonesia (BEI) dan situs resmi perusahaan sampel. Dalam penelitian ini perusahaan yang telah memenuhi kriteria yang ditetapkan dan dapat digunakan sebagai sampel dalam penelitian ini berjumlah 81 perusahaan.

\section{Pembahasan}

\section{Profitabilitas dan Devidend Payout Ratio}

Hipotesis satu yang menyatakan profitabilitas berpengaruh positif terhadap dividend payout ratio ditolak, nilai sig $0,546>\alpha 0,05$, koefisien regresi tidak searah dengan yang dihipotesiskan, maka hipotesis satu ditolak. Artinya profitabilitas yang dimiliki perusahaan tidak menjamin bahwa perusahaan tersebut juga akan membagikan dividen yang lebih banyak pula terhadap pemegang saham. Hai ini sesuai dengan penelitian yang dilakukan oleh
Sulistyowati (2010) yang menyatakan bahwa profitabilitas tidak mempunyai pengaruh yang signifikan terhadap dividend payout ratio. Hipotesis ini sesuai dengan packing order theory (Rosdini 2009) yang menyatakan bahwa perusahaan yang profitable memiliki dorongan untuk membayar dividen relatif rendah untuk pemegang saham dikarenakan perusahaan yang sedang tumbuh akan banyak menggunakan labanya untuk proyek-proyek investasi bukan untuk dibagikan kepada pemegang saham.

\section{Leverage dan Dividend Payout Ratio}

Hipotesis dua yang menyatakan leverage berpengaruh negatif terhadap dividend payout ratio ditolak, nilai sig $0,027<\alpha 0,05$, koefisien regresi tidak searah dengan yang dihipotesiskan, leverage tidak berpengaruh negatif terhadap dividend payout ratio. Artinya, semakin tinggi leverage suatu perusahaan maka akan semakin tinggi pula dividen yang dibayarkan. Keputusan dividen perusahan seringkali dicampuradukkan dengan keputusan pembiayaan dan investasi (Mahadwarta, 2002). Beberapa perusahan membiayai pengeluaran modal sebagian besar dari pinjaman, sehingga memberikan kas dividen, dalam kasus ini dividen yang tinggi adalah akibat keputusan peminjaman (borrowing decision). Hasil ini sesuai dengan penelitian yang dilakukan Mahadwarta (2002) yang membuktikan bahwa semakin tinggi leverage suatu perusahaan, maka akan semakin tinggi pula dividen yang dibayarkan.

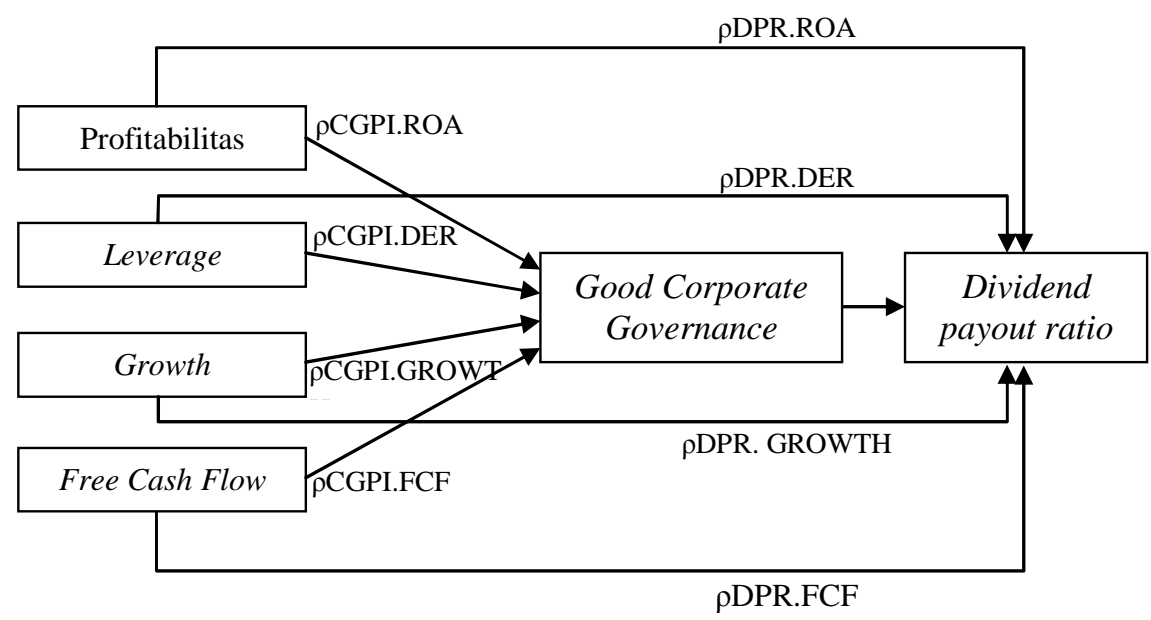

Gambar 2: Diagram Jalur 


\section{Growth dan Dividend Payout Ratio}

Hipotesis tiga yang menyatakan Growth berpengaruh negatif terhadap dividend payout ratio ditolak, nilai sig $0,022<\alpha 0,05$, koefisien regresi tidak searah dengan yang dihipotesiskan, growth tidak berpengaruh negatif terhadap dividend payout ratio. Artinya, semakin cepat tingkat pertumbuhan suatu perusahaan, maka semakin tinggi pula dividen yang dibayarkan. Perusahaan yang sedang tumbuh akan banyak mengeluarkan banyak dana. Dana yang dikeluarkan termasuk juga dana untuk pembagian dividen kepada pemegang saham. Semakin perusahaan tersebut tumbuh maka perusahaan membutuhkan suatu signal bahwa perusahaan tersebut memiliki prospek yang bagus dimasa datang. Hal ini sesuai dengan teori signaling yang menyatakan bahwa pembayaran dividen merupakan sinyal bagi investor luar mengenai prospek perusahaan dimasa datang, sehingga perusahaan yang semakin tumbuh akan banyak melakukan pembayaran dividen guna untuk memberikan signal bagi pemegang saham mengenai prospek perusahaan dimasa datang. Hasil ini sesuai dengan penelitian yang dilakukan oleh Hatta (2002), Sulistyowati (2010), dan Latiefasari (2011) yang menemukan bahwa growth tidak bepengaruh negatif terhadap dividend payout ratio.

\section{Free Cash Flow dan Dividend Payout Ratio}

Hipotesis empat yang menyatakan free cash flow berpengaruh positif terhadap dividend payout ratio diterima, nilai sig $0,011<\alpha 0,05$, koefisien regresi searah dengan yang dihipotesiskan, free cash flow berpengaruh positif terhadap dividend payout ratio. Artinya, semakin tinggi free cash flow yang tersedia bagi perusahaan maka akan semakin tinggi pula dividen yang dibayarkan. Semakin besar freecash flow yang tersedia dalam suatu perusahaan, maka semakin sehat perusahaan tersebut karena memiliki kas yang tersedia untuk pertumbuhan, pembayaran hutang, dan dividen. Jadi, semakin tinggi free cash flow perusahaan semakin tinggi pula dividen yang dibayarkan perusahaan, karena perusahaan memiliki cukup kas yang tersedia. Penelitian yang dilakukan oleh Rosdini (2009) menemukan bahwa free cash flow berpengaruh positif terhadap dividend payout ratio.

\section{Profitabilitas dan Corporate Governance}

Hipotesis lima yang menyatakan profitabilitas berpengaruh negative terhadap Corporate Governance ditolak, nilai sig 0,931> $>0,05$, koefisien regresi tidak searah dengan yang dihipotesiskan. Artinya, jika suatu perusahaan memiliki profitabilitas yang sedikit, maka perusahaan juga tidak akan membagikan dividen kepada para pemegang saham. Profitabilitas yang sedikit mengindikasikan bahwa perusahaan tersebut sedang tidak baik atau profitable. Perusahaan yang memiliki profitabilitas yang sedikit untuk melakukan kegiatan operasional perusahaan saja sulit, apalagi untuk membagikan dividen kepada para pemegang saham. Hasil ini sesuai dengan penelitian yang dilakukan oleh Sulistyowati (2010) yang menyatakan bahwa profitabilitas suatu perusahaan berhubungan positif terhadap Corporate governance.

\section{Leverage dan Corporate Governance}

Hipotesis enam yang menyatakan leverage berpengaruh positif terhadap Corporate Governance diterima, nilai sig $0,020<\alpha 0,05$, koefisien regresi searah dengan yang dihipotesiskan, leverage berpengaruh positif terhadap Corporate governance. Artinya, perusahaan yang memiliki tingkat hutang yang tinggi dalam struktur modalnya akan cenderung menjadi subjek untuk dikenai pengawasan oleh kreditor yang lebih ketat yang dinyatakan dalam kontrak hutang yang dibuat, kreditor sangat berkepentingan dalam praktik governance dari debiturnya dan memiliki kekuasaan yang lebih besar dibandingkan pemegang saham untuk memaksa perusahaan meningkatkan kualitas Corporate Governance perusahaan. Oleh karena itu, perusahaan yang memiliki leverage yang tinggi akan lebih banyak mengumumkan Corporate Governance perusahaanya guna untuk memiliki reputasi yang baik di mata kreditur. Hasil ini sesuai dengan penelitian yang dilakukan oleh Darmawati (2006) dan Sulistyowati (2010) yang menyata- 
kan bahwa leverage berpengaruh positif terhadap Corporate governance.

\section{Growth dan Corporate Governance}

Hipotesis tujuh yang menyatakan Growth berpengaruh positif terhadap Corporate Governance ditolak, nilai sig $0,344>\alpha 0,05$, koefisien regresi tidak searah dengan yang dihipotesiskan, growth tidak berpengaruh positif terhadap Corporate governance. Artinya, perusahaan yang sedang mengalami pertumbuhan atau pertumbuhan suatu perusahaan tersebut tinggi, maka akan banyak membutuhkan banyak dana untuk membiayai kegiatan perusahaan tersebut, sehingga perusahaan yang memiliki pertumbuhan yang tinggi akan mengabaikan corporate governance karena dana yang dibutuhkan sangat banyak untuk proyek-proyek investasi perusahaan. Hasil ini sesuai dengan penelitian yang dilakukan oleh Kusumawati (2007) yang menyatakan bahwa growth tidak beperngaruh positif terhadap corporate governance.

\section{Free Cash Flow dan Corporate Governance}

Hipotesis delapan yang menyatakan Free Cash Flow berpengaruh positif terhadap Corporate Governance ditolak, nilai sig 0,492> $>0,05$, koefisien regresi tidak searah dengan yang dihipotesiskan, free cash flow tidak berpengaruh positif terhadap Corporate governance. Artinya, semakin tinggi free cash flow suatu perusahaan maka akan semakin rendah CG yang diterapkan. Perusahaan dengan aliran kas bebas yang berlebihan akan cenderung mendorong terjadinya konflik keagenan berupa pemanfaatan dana proyek yang bertujuan untuk meningkatkan keuntungan manajer, sehingga dividen yang dibayarakan kepada pemegang saham sedikit (Murhadi 2008). Hasil ini sesuai dengan penelitian yang dilakukan oleh Murhadi (2008) yang menyatakan bahwa free cash flow suatu perusahaan yang semakin tinggi berpengaruh terhadap dividend payout ratio yang diterapkan suatu perusahaan. Semakin tinggi free cash flow suatu perusahaan, maka akan semakin tinggi pula dividen yang dibayarkan, karena pembiayaan dalam suatu perusahaan berasal dari pinjaman atau hutang.

\section{Corporate Governance dan Dividend Payout Ratio}

Hipotesis sembilan yang menyatakan Corporate Governance berpengaruh negatif terhadap Devidend Payout Ratio ditolak, nilai sig 0,419 $>\alpha 0,05$, koefisien regresi tidak searah dengan yang dihipotesiskan, corporate governance tidak berpengaruh negatif terhadap dividend payout ratio. Artinya, suatu perusahaan yang meiliki tata kelola yang baik akan berusaha memberikan signal positif kepada kreditur dengan membagikan dividennya kepada pemegang saham. Hipotesis kesepuluh yang menyatakan profitabilitas, leverage, growth, dan free cash flow berpengaruh terhadap divi dend payout ratio dengan Corporate Governance sebagai variabel intervening diterima, profitabilitas, leverage, growth, dan free cash flow berpengaruh terhadap dividend payout ratio dengan Corporate Governance sebagai variabel intervening. Hal ini dilihat dari koefisien langsung dan tidak langsung, koefisien tidak langsung semua variabel independen lebih besar dari koefisien pengaruh langsung, maka hipotesis diterima. Artinya variabel Corporate Governance merupakan variabel intervening yang ditambahkan dalam model penelitian.

\section{SIMPULAN}

Berdasarkan pengujian analisi regresi maka didapatkan hasil bahwa profitabilitas (ROA) tidak berpengaruh positif terhadap kebijakan dividen (DPR), leverage (DER) tidak berpengaruh negatif terhadap dividend payout ratio (DPR), growth (GROWTH) tidak berpengaruh negatif terhadap dividend payout ratio (DPR), free cash flow (FCF) berpengaruh positif terhadap dividend payout ratio (DPR), profitabilitas (ROA) tidak berpengaruh positif terhadap Corporate governance (CG), leverage (DER) berpengaruh positif terhadap Corporate governance (CG), growth (GROWTH) tidak berpengaruh positif terhadap Corporate governance (CG), free cash flow (FCF) tidak berpengaruh positif terhadap Corporate governance (CG), Corporate governance (CG) tidak berpengaruh negatif terhadap dividend payout ratio (DPR). 
Hasil pengujian path analysis menunjukkan bahwa nilai koefisien berpengaruh tidak langsung lebih besar dari nilai koefisien pengaruh langsung, maka profitabilitas (ROA), leverage (DER), growth (GROWTH), dan free cash flow (FCF) berpengaruh terhadap dividend payout ratio (DPR) dengan variabel Corporate governance (CG) sebagai variabel intervening, sehinga dalam penelitian ini Corporate Governance (CG) yang dimasukkan dalam model merupakan variabel intervening atau variabel penganggu antara profitabilitas (ROA), leverage (DER), growth (GROWTH), dan free cash flow (FCF) dengan dividend payout ratio (DPR).

\section{Keterbatasan}

Penelitian hanya menggunakan faktor fundamental perusahaan yang digunakan sebagai dasar untuk memprediksi DPR, yang meliputi ROA, DER, GROWTH, FCF, dan CG. Terdapat sejumlah variable lain yang dapat diduga mempunyai pengaruh. Selain itu, subjek yang diteliti masih terbatas kepada emiten yang tergabung dalam Corporate Governance Perception Index (CGPI). Kemampuan prediksi sebesar $16,4 \%$ mengindikasikan perlunya banyak faktor fundamental yang lain seperti likuiditas, solvabilitas dan aktivitas perusahaan dimasukkan sebagai prediktor dalam memprediksi DPR. Peneliti menyarankan untuk mempertimbangkan penambahan variabel independen seperti solvabilitas, likuiditas, atau aktivitas.

\section{Saran}

Seperti sudah disinggung di atas, nilai koefisien determinasi $\left(\mathrm{R}^{2}\right)$ sebesar 0,164 atau $16,4 \%$ hal ini bermakna bahwa $16,4 \%$ variasi DPR yang bisa dijelaskan oleh variasi dari kelima variabel bebas yaitu ROA, DER, GROWTH, FCF, dan CG sedangkan sisanya sebesar $83,6 \%$ dijelaskan oleh variabel lain yang tidak masuk dalam model. Hal ini mengindikasikan perlunya banyak faktor fundamental yang lain seperti likuiditas, solvabilitas dan aktivitas perusahaan dimasukkan sebagai prediktor dalam memprediksi DPR. Disamping itu juga perlu dilakukan perluasan penelitian yang menghubungkan antara variabel makro ekonomi dan non ekonomi terhadap DPR.

Variabel makro ekonomi yang mungkin berpengaruh terhadap DPR antara lain tingkat bunga, kurs rupiah terhadap valuta asing, neraca pembayaran, ekspor-impor dan kondisi ekonomi lainnya serta variabel non ekonomi seperti kondisi politik negara. Mungkin akan memberikan hasil yang lebih baik jika faktor fundamental lainnya seperti aktivitas perusahaan dimasukkan dalam model. Demikian pula variabel makro ekonomi (tingkat bunga, kurs rupiah terhadap valuta asing, neraca pembayaran, ekspor-impor dan kondisi ekonomi lainnya) serta variabel non ekonomi (seperti kondisi politik) mungkin signifikan berpengaruh terhadap DPR, mengingat sampai dengan saat penelitian berlangsung variabel-variabel makro ekonomi dan non-ekonomi tersebut masih menunjukkan kondisi yang belum stabil.

Penggunaan variabel intervening yang masih perlu diuji lagi oleh peneliti yang akan selanjutnya, karena dari penelitian sebelumnya hanya ada satu peneliti yang menggunakan variabel Corporate governance sebagai variabel intervening dan hasilnya ditolak, artinya variabel $C G$ bukan sebagai variabel intervening atau variabel penganggu, sehingga untuk penelitian mendatang diperlukan pengujian lagi untuk memperkuat hasil hipotesis ini.

\section{DAFTARREFERENSI}

Black, B. S., H. Jang, dan W. Kim. 2006. Predicting firms' corporate governance choices: Evidence from Korea. Journal of Corporate Finance 12 (3): 660-691.

Daniri, M. A. 2006. Good corporate governance: Konsep dan penerapannya dalam konteks Indonesia. Jakarta: Ray Indonesia.

Darmawati, D., K. Khomsiyah, dan R. G. Ayu. 2006. Hubungan corporate governance dan kinerja perusahaan. Jurnal Riset Akuntansi Indonesia 8 (1): 65-81.

Darminto. 2008. Pengaruh profitabilitas, likuiditas, struktur modal, dan kepemilikan 
saham terhadap kebijakan dividen. Jurnal Ilmu-Ilmu Sosial 1 (2): 87-97.

Faisal. 2006. Hubungan antara set kesempatan investasi, tata kelola perusahaan, dan kinerja. Wahana Akuntansi Jurnal Ilmiah 1 (2): 106-22.

Ghozali, I. 2009. Aplikasi analisis multivariate dengan program SPSS. 4th ed. Semarang: Badan Penerbit Universitas Diponegoro.

Hatta, A. J. 2002. Faktor-faktor yang mempengaruhi kebijakan dividen: Investigasi pengaruh teori stakeholder. Jurnal Akuntansi dan Auditing Indonesia 6 (2): 1-22.

Jiraporn, P., J. Kim, dan Y. S. Kim. 2011. Dividend payouts and corporate governance quality: An empirical investigation. Financial Review 46 (2): 251-279.

Kowalewski, O., I. Stetsyuk, dan O. Talavera. 2007. Corporate governance and dividend policy in Poland. http://fic.wharton.upenn.edu/fic/papers 107/0709.pdf (diakses 17 Maret 2014).

Kusuma, H. 2004. Hubungan dividen inisiasi dan informasi asimetri: Pendekatan hazard rate. Jurnal Siasat Bisnis 1 (9): 15-34.

Kusumawati, D. N. 2007. Profitability and corporate governance disclosure: An Indonesian study. Jurnal Riset Akuntansi Indonesia 10 (2): 131-46.

Mahadwarta, P. A. 2002. Interdependensi antara kebijakan leverage dengan kebijakan dividen: Perspektif teori keagenan. Jurnal Riset Akuntansi, Manajemen, dan Ekonomi 2 (2).

Marpaung, E. I, dan B. Hadianto. 2009. Pengaruh profitabilitas dan kesempatan investasi terhadap kebijakan dividen: Studi empiris pada emiten pembentuk indeks LQ45 di bursa efek Indonesia. Jurnal Akuntansi 1 (1): 70-84.
Murhadi, W. 2008. Pengaruh tahapan daur hidup perusahaan, good corporate governance, set kesempatan investasi, aliran kas bebas, dan struktur kepemilikan terhadap nilai perusahaan: Tinjauan teoritis. Jurnal Ekonomi \& Bisnis 12 (2): 14-28.

Prihantoro. 2003. Estimasi pengaruh dividen payout ratio pada perusahaan publik di Indonesia. Jurnal Ekonomi \& Bisnis 1 (8): 7-14.

Riyanto, B. 2001. Dasar-dasar pembelanjaan perusahaan edisi empat. Yogyakarta: Badan Penerbit Gadjah Mada.

Rosdini, D. 2009. Pengaruh free cash flow terhadap dividen payout ratio. Working Paper in Accounting and Finance. Bandung.

Rozeff, M. S. 1982. Growth, beta, and agency cost as determinants of dividend payout ratio. Journal of Financial Research 5 (3): 249-259.

Sugiarto. 2008. Kebijakan dividen perusahaanperusahaan terbuka non keuangan yang dikontrol keluarga.Jurnal Akuntansi \& Keuangan 7 (2): 135-149.

Suharli, M. 2007. Pengaruh profitability dan investment opportunity set terhadap kebijakan dividen tunai dengan likuiditas sebagai variabel penguat. Jurnal Akuntansi \& Keuangan 9 (1): 9-17.

Suharli, M., and H. Sofyan. 2004. Studi empiris terhadap faktor tertentu kebijakan jumlah dividen. Media Riset Akuntansi, Auditing, Dan Informasi 4 (3): 223-245.

Sulistiyowati, I. 2010. Pengaruh profitabilitas, leverage, dan growth terhadap kebijakan dividen dengan good corporate governance sebagai variabel intervening. Purwokerto.

Tampubolon, M. P. 2005. Manajemen keuangan (finance management). Bogor: Ghalia Indonesia. 